\title{
A PROSPECTIVE STUDY OF THE EFFICACY OF LOW DOSE NITROFURANTOIN IN PREVENTING URINARY TRACT INFECTIONS IN SPINAL CORD INJURY PATIENTS, WITH COMMENTS ON THE ROLE OF PSEUDOMONADS
}

\author{
By Rosemary Lindan, M.B., B.S. and Elizabeth Joiner, R.N. \\ Spinal Cord Injury Service, Highland View Hospital, Cleveland, Ohio 44Io9, U.S.A.
}

Summary. From the results we obtained it seems clear that, even in the presence of Foley catheters and a history of previous urinary infections, low dose antibacterial therapy is effective in preventing repeated invasion of the bladder urine by pathogenic organisms in spinal cord injured patients. It should be emphasised however that the quality of catheter care must also be of high standard and that antibacterials alone cannot compensate for poor care. Nitrofurantoin in the dose we use has proven to be non-toxic and free of side effects, and has not resulted in the emergence of drug resistant bacterial strains. Moreover it would seem that pseudomonas organisms may, in the absence of traumatic catheter techniques be safely left to browse undisturbed in the neuropathic bladder.

Key words: Nitrofurantoin; Pseudomonas; Urinary catherisation; Neurological dysfunction of bladder; (Bladder, neurogenic-Index Medicus, U.S.A. listing).

\section{Introduction}

THIS paper represents another step in our continuing efforts over the past 20 years to minimise the morbidity due to urinary infections in our spinal cord injured patients. In addition to providing a team of catheter-care technicians trained in aseptic technique and the increasing use of intermittent catheterisation, we have also attempted to reduce bladder infections further by giving small doses of an antibacterial drug on a continuous basis. This latter practice, however, is not universal and has been subject to the legitimate criticism that, until very recently, there were no prospective studies to support it. In the last i 8 months two studies have been reported on the effectiveness of trimethoprim-sulfamethoxazole (TMP-SMX) in patients on an intermittent catheterisation programme since injury (Dubo et al., I982; Maynard and Diokno, 1983). On the other hand, earlier reports on the use of various antibacterials in patients with Foley catheters have varied from poor (Kostiala et al., I982) to useless (Jackson, I98 I).

Patients admitted to our spinal cord injury unit come to us weeks or sometimes months following their injury, having been hospitalised in a neurosurgical or intensive care unit elsewhere, often wearing Foley catheters and usually with active urinary infections. This situation, although no longer universal, is still not uncommon in the U.S. and it therefore seemed of interest to carry out a prospective study on the patient population which passes through our service, of the effectiveness of continuous antibacterials, combined with good catheter-care on the incidence of urinary infections.

We abandoned the use of TMP-SMX as preventive therapy several years ago when we noted the emergence of a drug resistant enterobacter 
strain in those patients receiving low doses of this medication in our hospital. Instead, we have used nitrofurantoin $50 \mathrm{mg}$ twice daily, and this paper presents the results of a prospective study of its efficacy in 60 hospitalised patients.

\section{Study Group}

From October I980 to February I982 patients admitted to our spinal cord injury service were assigned to one of two groups. Group I was to receive $50 \mathrm{mg}$ of nitrofurantoin (in the form of encapsulated macrocrystals) every I 2 hours; Group 2 was to receive no antibacterial drug unless diagnosed as having a urinary infection. Apart from this all patients received the same level of catheter care (Lindan, I969).

In addition to the more recently injured patients admitted from acute facilities, some of the patients entering the study were being readmitted for elective surgery or late complications such as pressure sores. The interval between injury and entry into this study ranged from I day to 6 months for first admissions and averaged 44 days (42 days Group I; 46 days Group 2). Five of the patients were readmissions of from 2-I I years following injury with an average of 5.5 years. (Three of these patients were in Group I and 2 were in Group 2.) All but two of the patients had a prior history of one or more UTIs. Those who were infected at the time of admission were treated with specifically indicated antibacterial drugs so that all patients had sterile urines at time of entry into the study.

Initial investigations included cystograms and cystometrograms, intravenous pyelograms (IVP) and creatinine clearances. Two patients refused IVP and had sonograms of the abdomen performed. The IVP on one patient showed some fullness of the right renal pelvis and minimal blunting of calyces, but there were no other indications of upper tract infections in this or other patients admitted to the study, and renal function studies were normal in all cases.

The age, sex, levels of injury and catheter status of the patients is seen in Tables I, II and III.

TABLE I

Study population-age and sex (6o patients)

\begin{tabular}{lcrrrr}
\hline & & Group I & Group 2 & \multicolumn{2}{c}{ Totals } \\
\hline Sex & $M$ & 22 & 27 & 49 & $(82)$ \\
Ages & F & 9 & 2 & I I & $($ I 8$)$ \\
(range 7-62 years, & $\leqslant 20$ & 27 & I8 & 45 & $(75)$ \\
average 28 years) & 2 I -45 & I & 5 & 6 & $($ I0) \\
\hline
\end{tabular}

TABLE II

Study population-level of injury (6o patients)

\begin{tabular}{lrcc}
\hline & Group I & Group 2 & Totals \\
\hline Cervical & 2 I & I5 & 36 \\
Thoracic & 4 & 9 & I3 \\
Lumbar & 6 & 5 & I I \\
\hline
\end{tabular}


TABLE III

Study population-catheter status

\begin{tabular}{lccc}
\hline & Group I & Group 2 & Totals \\
\hline Foley & I4 (7 females) & I I (I female) & 25 (8 females) \\
Intermittent catheter & I4 (2 females) & I 3 (I female) & I7 (3 females) \\
$\begin{array}{l}\text { External with reflex } \\
\text { voiding }\end{array}$ & 3 & 5 & 8 \\
\hline
\end{tabular}

There were 44 complete lesions and 16 incomplete lesions (seven in Group I and nine in Group 2) and all patients had neurological dysfunction of the bladder as demonstrated by $\mathrm{CO}_{2}$ cystometry.

\section{Laboratory Methods}

A urinalysis, sediment examination and culture were carried out on urines of all patients at least once weekly. In addition, 'streak' cultures were made daily, on 5 days each week, from urines of patients on intermittent catheterisation.

A urine was considered to be infected if 20 or more pus cells were seen in five consecutive high power fields of unspun urine and $10^{5}$ or more colony forming units of uropathogenic organisms per $\mathrm{ml}$ were obtained on culture. The streak cultures were not quantitative but any growth was checked by a full urinalysis and colony count on the following day. We defined uropathogens (as opposed to colonisers), on the basis not only of colony counts but on our previous observations that, in the neuropathic bladder certain organisms are consistently noninvasive while others are frequently or usually invasive, as judged by antibody coating studies and continuing clinical observations of over 20 years. The most frequently encountered of the noninvasive organisms are Candida albicans and pseudomonads, and we will present further evidence later in this paper to support our practice of leaving pseudomonads undisturbed. Those organisms, on the other hand, which have been found to be true pathogens are E. coli, proteus, klebsiella and enterobacter organisms, as was reported to this Society in Holland in 1980 (Lindan, 198I). In the present study we treated infected patients growing significant numbers of these uropathogenic organisms only, and did not treat patients growing 'colonisers' regardless of the numbers of CFU $/ \mathrm{ml}$. The patients were studied in this way for periods of 7-I 7 weeks 'with an average of I I 8 weeks.

\section{Results}

All patients showed bacteriuria at least once during the study period. However, significant bacteriuria with a pathogenic organism accompanied by an increase in pyuria ('laboratory infection') was seen in eight patients only in Group I who were receiving nitrofurantoin, but occurred in 25 patients in Group 2 who were receiving no nitrofurantoin (Table IV). In only one patient in each group was there a 'clinical infection' with accompanying fever and leukocytosis.

Multiple laboratory infections were common in Group 2. Twenty-five patients in this group experienced 60 episodes of infection, as compared with only one patient in the treated group who developed two infections. 
TABLE IV

Incidence of urinary infections

\begin{tabular}{ccc}
\hline Incidents of UTI & $\begin{array}{c}\text { Group I NF } \\
\text { (3 I patients) }\end{array}$ & $\begin{array}{c}\text { Group 2 no NF } \\
\text { (29 patients) }\end{array}$ \\
\hline O & $24(74 \%)$ & $4($ I4 $\%)$ \\
I & 7 & 6 \\
2 & I & 9 \\
3 & 0 & 4 \\
4 & 0 & 6 \\
Total UTIs & 9 & 60 \\
& (8 patients) & (25 patients) \\
\hline
\end{tabular}

* NF-nitrofurantoin $50 \mathrm{mg} \mathrm{q.} 12 \mathrm{~h}$.

TABLE V

Incidence of sterile urines and pseudomonas colonisation

\begin{tabular}{|c|c|c|}
\hline & $\begin{array}{c}\text { Group I } \\
\text { (3I patients) }\end{array}$ & $\begin{array}{c}\text { Group 2 } \\
\text { (29 patients) }\end{array}$ \\
\hline $\begin{array}{l}\text { Weeks of sterile } \\
\text { urines }\end{array}$ & $\begin{array}{c}35 \\
\text { (I4 patients) }\end{array}$ & $\begin{array}{c}\text { I I } \\
(7 \text { patients })\end{array}$ \\
\hline $\begin{array}{l}\text { Pseudomonas } \\
\text { isolated }\end{array}$ & 23 patients & I7 patients \\
\hline
\end{tabular}

Fourteen of the 3 I patients in Group I experienced a total of 35 weeks of sterile urines, without pathogens or colonisers. Pseudomonas was isolated on one or more occasions from urines of 23 patients in this group.

On the other hand only seven of the 29 patients in Group 2 attained sterile urines for a total of I I weeks, and pseudomonas was isolated from the urines of 77 (Table V).

\section{Discussion}

The role of pseudomonas in the neuropathic bladder is an interesting one. Although Ps. aeruginosa is an undoubted pathogen in immunocompromised hosts, such as leukaemic or other cancer patients, it rarely if ever is capable of invading in the presence of normal immune mechanisms; in order to infect healthy animals repeated intravenous injections must be given to growing cultures. It is primarily an opportunist and a coloniser, and its success in this rôle is probably due to the fact that it produces antibiotic substances which suppress other competing bacteria (Bouchard, I 889). An extract of pseudomonas, called 'pyocyanase' was the first antibiotic ever used, in I 899, for the treatment of anthrax in cattle (Emmerich and Loew, I 889). In I94I, in Florey's laboratory in Oxford, there were shown to be three antibacterial substances present in pyocyanase (Schoental, I 94 I). The ability to suppress other bacteria such as $E$. coli is a property of old pseudomonas cultures containing dead and lysed organisms, and this is easily demonstrated by placing a drop of a 2-day old broth culture of pseudomonas onto a freshly seeded lawn of $E$. coli on a McConkey agar plate. After I 8 hours incubation there is what appears to be a punched out hole in the growth of the $E$. coli. If the same procedure is adopted with a drop of 
proteus broth culture instead of the pseudomonas, the $E$. coli will grow right through it.

We have continuous laboratory records of some of our patients going back to 1969 showing repeated isolations of pseudomonas from the urine over periods of years during which time the patients remained asymptomatic and their renal function studies have continued to be normal. It is in fact probable that the pseudomonas, by virtue of its antibiotic production, is acting as a 'keeper at the gate' in the bladders of these patients, preventing infections by more pathogenic organisms.

\section{RÉSUMÉ}

Les résultats obtenus dans ce travail permettent de conclure que, chez les malades avec des lésions traumatiques de la moëlle épinière, même si ils ont un cathéter de Foley et des infections dans leur passé, le traitement antibactérien à doses réduites prévient l'invasion de la vessie urinaire par les organismes pathogéniques. Cepandant il faut souligner l'importance de la qualité des soins du cathéter; le traitement antibactérien ne peut pas remplacer ces soins. La nitrofurantoine, dans une dose de $50 \mathrm{mg}$ deux dois part jour s'est montrée non-toxique et sans effets secondaires et n'a pas produit des souches bactériennes résistantes. D'ailleurs, il paraît que si la colonisation par les pseudomonas se produit en absence de techniques de cathétérisme traumatisantes, on peut laisser les malades sans traitement, sans les mettre en danger.

\section{ZUSAMMENFASSUNG}

Das Resultat dieser Arbeit zeigt dass anti-Bakterische Therapir mit kleinen Dosen effektiv ist, die Invasion des Blasenurins mit pathogenen Bakterien in rückenmarksgelähmten Patienten, selbst wenn ein Foley Katheter verwendet wird, zu verhüten. Es muss aber doch betont werden dass eine sehr sorgfältige Katheter-Pflege nötig ist, und dass antiBakterische Behandlung allein nicht für unsorgfältige Behandlung kompensieren kann. Nitrofurantoin in Dosen von $50 \mathrm{mg}$ zweimal täglich hat sich als nicht toxisch und frei von Seiteneffekten erwiesen, und hat nicht zur Heranzüchtung von resistenten Bakterien geführt. Schliesslich scheint es dass Kolonisation mit Pseudomonas in Abwesenheit von traumatischer Kathetertechnik unbehandelt gelassen werden kann.

\section{REFERENCES}

BOUCHARD, C. (I889). Influence qu'excerce sur la maladie charbonneuse l'innoculation du bacille pyocyanique. C. R. Acad. Sci., Paris 108, 713-714.

Dubo, H. I. C., Schryvers, O., Ramsey, E., Harding, G. \& Ronald, A. (I982). Intermittent catheterisation and low dose trimethoprim-sulfamethoxazole (TMP-SMX) prophylaxis in bladder management of acute spinal cord injury patients. Proc. Eighth Annual Scientific Meeting, American Spinal Injury Association. 43-46.

EMMERICH, R. \& LoEw, O. (I899). Bakteriolytiche enzyme als Ursache der erworbenen Immunitaet und die Heilung von Infektionskrankheiten durch dieselben. $Z$. Hyg. InfektKr., 31, I-65.

JACKSON, G. G. (I98I). Consideration of antibiotic prophylaxis in non-surgical high risk patients. Am. F. Med., 70, 467-473.

Kostiala, A. A., Nyr'en, P., Jokinen, E. J. \& Runeberg, L. (1982). Prospective study on the appearance of antibody-coated bacteria in patients with an indwelling urinary catheter. Nephron, 30 (3), 279-285.

LINDAN, R. (1969). The prevention of ascending, catheter-induced infections of the urinary tract. F. Chron. Dis., 22, $32 \mathrm{I}-330$.

LINDAN, R. (I98I). The significance of antibody coated bacteria in neuropathic bladder urines. Paraplegia, 19, 2 16-219.

MAYNARD, F. \& DIOKNO, A. (I983). Clean intermittent catheterisation as initial management for spinal cord injured patients. Proc. Ninth Annual Scientific Meeting, American Spinal Injury Association. 42 (only).

SchoENTAL, R. (I94I). The nature of the antibacterial agents present in pseudomonas pyocyanea cultures. Brit. F. Exp. Pathol., 22, 137-147. 